\title{
Happy campers: The Topp Twins, queerness and New Zealand identity
}

\author{
Matthew Bannister \\ WaikAto InSTITUTE OF TECHNOLOGY
}

\begin{abstract}
Vanessa Knights and Tony Biddle write that conceptualisations of the national have been somewhat sidelined in a world increasingly dominated by the processes of globalisation, deterritorialisation, transmigration and forms of cultural hybridity. As a multicultural postcolonial settler society, Aotearoa/New Zealand has a troubled relationship with national identity. In relation to local popular music, Tony Mitchell argues for homologies with landscape, using a psycho-geographical approach, while Nabeel Zuberi suggests that the emphasis on local identity is too prescriptive, especially given the ways it functions in public and institutional discourse. And clearly multiculturalism in New Zealand problematises any representation of unitary identity; rather it becomes a question of mapping multiple identifications. Cultural production, in this case popular entertainment, is ambivalently placed in relation to national discourses, both forming and responding to them. Popular entertainers may identify with minority groups that are excluded from the national hegemonic. Arguably performers identifying with minority positions are particularly aware of the performativity of identity. The Topp Twins, two lesbian singers, entertainers, cowgirls and good blokes to boot are a cultural institution in New Zealand. The paper explores how the Topp Twins negotiate identifications around the national in their performances, especially in terms of gender and ethnicity, for example in the recent documentary Untouchable Girls, and how reading the Topp Twins feeds back into the New Zealand musical identity debate.
\end{abstract}

Situating popular musics: IASPM 16th International Conference Proceedings, pp. 33-28

CC 3.0 2012 IASPM | International Association for the Study of Popular Music | ISSN: 2225-0301

http://www.iaspm.net/proceedings | DOI 10.5429/2225-0301.2011.05 
KEYWORDS: gender; national identity; Aotearoa/New Zealand; postcolonial (settler) culture; performance.

The Topp Twins, yodelling lesbian twins from Huntly, New Zealand, are well-loved "Kiwi" entertainers ("Kiwi" refers to mainstream white/"Pakeha" culture). The recent documentary Untouchable Girls (2009), the highest-grossing documentary in New Zealand cinema history, represents them as uniting opposing elements in New Zealand culture: protest and entertainment; lesbian and straight; indigenous Maori and Pakeha; critical respect and popularity. They are singers, stand-up comedians, buskers, television stars, cross-dressers and burlesque entertainers, starting a local tradition of comedy/music double acts (the Front Lawn, the Flight of the Conchords). How have they gained this degree of cultural mobility? How does their identity as New Zealanders (indeed "Kiwis") relate to their identity as "queers"? How do their performances unite disparate, indeed contradictory, elements in New Zealand identity? I have considered aspects of queer and postcolonial theory, focusing mainly on Jodie Taylor, Richard Dyer, Nick Perry and Judith Halberstam to explore the relationship between gender and cultural identity in the Topp Twins.

The Topps' "Kiwi" credentials are easily established - country girls, singing folk/ country music and later constructing a series of comic national stereotypes, male and female. They started busking on Queen Street, Auckland in the late 1970s, where they attracted large crowds - busking is readily interpreted as "grass-roots authenticity", both in terms of locality and lack of technological artifice. A series of campus tours in the early 1980s gave them "alternative" credibility, but they also appeared on television programmes and hosted a comic television series from 1997 to 1999. The latter especially showcased comic "characters" such as Camp Mother and Camp Leader, Ken and Ken (Kiwi blokes, farmers) etc. Their recorded musical output has been reasonably regular since 1982, totalling nine releases and gradually moving from alternative folk to country. This trajectory broadly follows that of "womyn's music", which might also explain why their recordings have received little attention from local rock critics (Dix 2005; Eggleton 2003).

Jodie Taylor (2009, p. 51) writes that womyn's music, that is, lesbian folk acoustic singer-songwriters, was a 1970s reaction to male dominance in popular music: "Folk was already imbued with political themes and its sound was considered 'softer' [...] and therefore less masculine", favouring "a DIY separatist [...] nonhierarchical, and participative [...] approach". Taylor suggests that womyn's music's focus on "binarised gender differences proved problematic for future generations of women" (ibid., p. 52) - indeed, womyn's music has remained marginal. But the Twins' act is both popular, and more than music, demanding an alternative frame of reference - Richard Dyer's "entertainment".

Dyer (1992, p. 17) defines "entertainment" as "performances produced for profit, [for a] generalized audience by a trained paid group [...] which have the sole (conscious) aim of providing pleasure", specific to contemporary Western capitalist culture: stage musicals, music hall, variety television spectaculars, pantomime, caba- 
ret. The Twins are entertainment because they are clearly not "art" - edifying, elitist, refined or difficult - and because they present "a string of short items [including] popular or vulgar reference [...] implicit sexuality and open sentimentality" (ibid., p. 13), aimed at a mass audience. The "good feelings" that entertainment provides are conveyed through an affective rather than a representational code: what Dyer terms non-representational signs - colour, texture, movement, rhythm, melody, which generate qualities of energy, abundance, intensity, transparency and community (ibid., p. 18). The Twins convey energy through vocal performance, constant movement, banter and slapstick; abundance though multiple comic personae. Intensity marks their singing style - two strong, clear, almost identical voices, with little vibrato, and occasional yodelling! Transparency is represented though improvisatory modes of performance, audience interaction, adlibs, singalongs and the acoustic folk mode, which also connotes community through local references, inclusivity, and egalitarianism through audience involvement and the "equal" relation between performers (as twins).

However, Dyer's split between entertainment's conservative comfort and art's radical struggle overlooks how the Twins are both: "an anarchist variety act" (Billy Bragg, quoted in Untouchable Girls). Their roots in folk protest are obvious in their minimalist performance - two women with guitars and some funny costumes - and in the political content of their act. Dyer tends to emphasise entertainment's being "for the people" not "by the people" (ibid.). But outside the UK, folk populist politics (for example Woody Guthrie) make more sense.

Dyer (ibid, p. 138) compares entertainment and gay culture: "Basically [camp] is a way of prising the form of something away from its content, of revelling in the style while dismissing the content as trivial", hence the emphasis on non-representational signs. Camp appropriates entertainment's vulgarity, tackiness, ephemerality, a Foucauldian reverse discourse by which "trash" is worn with pride. However, the Twins are also mainstream Kiwi, a culture not particularly accepting of gender and sexual deviance. Dyer uses camp readings of John Wayne to argue the danger of confusing heterosexual and homosexual camp, an idea picked up by Nick Perry (1998, p. 12):

Antipodean camp is distinguished by a generically nationalist inflection of the distinction which Dyer makes [...] the forms of cultural dominance to which it is a response are the master discourses of $(\mathrm{m})$ other countries, and the versions of cultural identity that it prioritizes are those which amplify the accident of place.

Kiwiana, signifiers that connote "locality", are examples of Antipodean camp: Marmite, Weetbix, tomato sauce, sheep, plastic tikis, lilos, jandals, beer (Bell 1996, p. 181). Paradoxically, all these signifiers come from somewhere else, and are mass manufactured, commercial products. Kiwiana is "trash" - fast food, cheap clothing, plastic souvenirs, symbolic of a New World, naïve but vigorous working class, rather than the Old World bourgeois coloniser culture. It is a kind of fakery, but 
"the signs [...] go on working [...] to call up nationalist sentiments through cultural images [...] constructed in accordance with bricoleur tactics, placed in quotation marks by the signalling of their own fabrication and asserted through self-mockery" (Perry 1998, p. 12). The relationship between camp and Kiwi, queer and national identity is based around the common identification of both with and as (white) trash. The Topp Twins reveal the latent queerness of "Kiwi" culture.

Perry (ibid., p. 8) argues that both camp and postcolonial cultures "offer ways of making something out of marginality through representations which otherwise serve to confirm and reinforce it". But he reads a sinister quality into such practices; a "bleak edge to the style's surface whimsy, the difficulty of determining whether its practitioners be categorized as affirmatively comic or resignedly ironic [...]. Wavering between parodying, and participating in, received critical assumptions about New Zealand popular culture" (ibid.). He discusses an oscillation between dark drama and banal comedy characteristic of New Zealand film ("Kiwi Gothic"). But bleakness seems foreign to the Topp Twins. There is a self-deprecating, self-mocking quality to their performances, but integrated into a spectacle of entertainment. They are ironic, but affirmative. How can they be both?

The problem and solution lie in Dyer's John Wayne example, cited by Perry. Camp for Dyer is gay male while "straight camp allows images of butchness to retain their hold even while they are apparently being rejected" (Dyer 1992, p. 145). "Butchness" pejoratively implies straight masculinity. But "butch" men can be homosexual, too. And what about butch women like the Topp Twins? Two points arise - how can camp be wrested away from Dyer's definition of it as exclusive to gay men? And does this reformulation allow a more affirmative reading of Antipodean camp?

Judith Halberstam (1998, p. 1) argues that if gender has no necessary relationship with sex, then female masculinity should be just as valid as male masculinity. But she finds that ideologically, gender is not reversible - men can perform femininity, but not the other way round, because while femininity is masquerade, masculinity is "real". Halberstam (ibid., pp. 125-131; 232-240) discusses two examples of "female masculinity": the stone butch and the drag king. The stone butch is a hard woman, the masculine end of the butch/femme continuum. She is defined as an active partner who spurns reciprocation - "untouchable", a term which also occurs in the Twins' theme song "Untouchable Girls". Drag kings are female impersonators of men, clearly relevant to the Twins' Ken and Ken. Halberstam argues that the masculinity of the stone butch renders her marginal within both queer and straight communities - but once again, this doesn't seem to apply to the Topp Twins. Queer scholars dispute whether camp is assimilable to lesbianism, Halberstam (ibid., p. 238) stating that "it tends to be the genre for an outrageous performance of femininity (by men or women) rather than outrageous performance of masculinity". Halberstam's accounts of drag kings emphasise awkwardness in performance, because of the "non-theatricality" of masculinity. However, I don't detect a similar "awkwardness" in the Topp Twins' Ken and Ken, perhaps because the Topps' double act format allows them to theatricalise masculinity more effectively - homosocial banter and "mateship" depend on dialogue. 
Dyer suggests that some kinds of camp are more authentic than others. But "authentic camp" is a contradiction in terms. Perry applies a similar distinction to New Zealand culture, to suggest the ongoing ambivalence of being "authentically Kiwi". But camp recognises this as a false opposition - appearances are reality; there is nothing underneath. Antipodean camp is a reformulation of cultural cringe - postcolonial anxiety about authenticity. The Topp Twins do not cringe. They truly are "happy campers".

Notably Perry's examples of Antipodean camp are mostly masculine, which is strongly associated with local discourses of national identity (Bannister 2005). But precisely because masculinity is supposed to be "real", New Zealand national identity is always troubled by inauthenticity. As queer Kiwi women entertainers, the Twins have a foot in both camps, celebrating Kiwiana on the one hand but also with a queer awareness that identity is always performed. A Topp Twins performance creates communal identity - indeed they note in the documentary the role singing has in creating communities. The Twins are experienced at creating identity and solidarity through performance, and this is a role they continue to perform.

The Topp Twins also "play men" in a way that seems to challenge Halberstam's contention that gender impersonation is a male-only affair. A comparative study by FCB New Zealand of advertising semiotics in the United States and New Zealand suggests that sexual difference is less emphasised in the latter, what is termed "the gender-blender phenomenon" (Barton 2005). Halberstam (1998, pp. 57-58) also notes that "some rural women may be considered masculine by urban standards". The Twin's androgyny facilitates gender ambiguity, but also renders their female characters as constructed as their male ones (ibid.). Because of the strong rural iconography of "Kiwi" culture, perhaps female masculinity is more tolerated in New Zealand than the United States, albeit serving patriarchal interests, but such practices are always also available for appropriation, as has occurred with the Topp Twins.

\section{Conclusion}

I applied five approaches to the Topp Twins: womyn's music, "entertainment", Antipodean camp, female masculinity, and advertising semiotics, employing each to critique the last: womyn's music didn't sufficiently encompass the range of the Twins' repertoire and modes of performance; entertainment overlooked the possibility of a folk populist politics. Antipodean camp develops the parallel between queer and postcolonial cultures as types of marginality, ironically appropriating "trash" but with lingering doubts about inauthenticity, which relate partly to New Zealand's historic identification with masculinity. Female masculinity, however, provides a non-essentialist way of thinking about masculinity and opens it up for appropriation by queer groups, and studies of advertising semiotics suggest some local acceptance of this. The Twins' "blokiness", combined with their participatory, comic and campy approach, allow them to "pass" as "normal Kiwis" despite or because of being queer women. Such cultural mobility and ambiguity combine contradictory elements in their audience and represent New Zealand as an inclusive rather 
than exclusive culture, to celebrate a shared local "uniqueness" and marginality, in a queer, not essentialist, way.

\section{REFERENCES}

Bannister, Matthew. 2005. "Kiwi blokes: Recontextualising Pakeha masculinities in a global setting". Genders online, Issue 42.

Barton, Chris. 2005. "Where women are real men". New Zealand Herald, February $5<$ http://www.nzherald.co.nz/news/print.cfm?objectid=10009522>; accessed: 14.feb. 2011.

Bell, Claudia. 1996. Inventing New Zealand: Everyday myths of Pakeha identity. Penguin, Auckland.

Dix, John. 2005. Stranded in paradise: New Zealand rock and roll, 1955 to the modern era. Penguin, Auckland.

Dyer, Richard. 1992. Only entertainment. Routledge, New York.

Eggleton, David. 2003. Ready to fly. Craig Potton, Nelson.

Halberstam, Judith. 1998. Female masculinity. Duke University Press, Durham, NC.

Perry, Nick. 1998. Hyperreality and global culture. Routledge, London and New York.

Taylor, Jodie. 2009. "Lesbian dissonance, music cultures and mainstreams". In Strong, Catherine and Phillipov, Michelle (eds.), Stuck in the middle: proceedings of the 2008 IASPM-ANZ conference, IASPM-ANZ, pp. 49-57.

The Topp Twins: Untouchable girls. 2009. Director: Pooley, Leanne, Diva Films, Auckland. Documentary. 